Kurniadie, D. • Y. Sumekar • I. Buana

\title{
Pengaruh berbagai jenis surfaktan pada herbisida glufosinat terhadap pengendalian gulma dan hasil tanaman jagung (Zea mays 1.) di Jatınangor
}

\section{The impact of several types of surfactant in glufosinate herbicide on the weeds control and corn (Zea mays L.) yield in Jatinangor}

\author{
Diterima : 17 Agustus 2017/Disetujui : 25 Agustus 2017 / Dipublikasikan : 31 Agustus 2017
}

CDepartment of Crop Science, Padjadjaran University

\begin{abstract}
The addition of surfactant is expected to optimize weeds control in herbicide application. The purpose of this research was to find out the impact of surfactant with different types and concentrations in glufosinate herbicide on weeds control of corns (Zea mays L.). This research was conducted from September to December 2016 in Ciparanje, Universitas Padjadjaran. The output data of this research was analyzed using Random Block Design (RBD) with 9 treatments such as: Glufosinate $+15 \%$ nonionic surfactant; Glufosinate $+15 \%$ anionic surfactant; Glufosinate $+15 \%$ cationic surfactant; glufosinate; Glufosinate $+20 \%$ nonionic surfactant; Glufosinate $+20 \%$ anionic surfactant; Glufosinate + $20 \%$ cationic surfactant; Mechanical weeding; Control (no treatment), each treatment was repeated 3 times. The difference among treatments was examined using $\mathrm{F}$ test, while the difference of the average values of the treatments was examined using Duncan test on the real stage of $5 \%$. The result of this research showed that glufosinate without surfactant could hold down the growth of weeds, so that the best crop yield was obtained with average weight of 12,41 ton ha-1 of dry seeds.
\end{abstract}

Keywords: Corn · Glufosinate · Surfactant

Sari Penambahan surfaktan diduga dapat mengoptimalkan pengendalian gulma menggunakan herbisida. Penelitian ini bertujuan untuk mengetahui pengaruh jenis dan konsentrasi surfaktan pada pengendalian kimia menggunakan herbisida Glufosinat terhadap gulma di pertanaman jagung (Zea mays L.). Penelitian ini dilakukan dari bulan September sampai dengan Desember

\footnotetext{
Dikomunikasikan oleh Uum Umiyati

Kurniadie, D. · Y. Sumekar • I. Buana

Departemen Budidaya Pertanian, Fakultas Pertanian,

Universitas Padjadjaran

Korespondensi: yayan.sumekar@gmail.com
}

2016 di Kebun Percobaan Ciparanje Unpad. Rancangan perlakuan yang digunakan adalah Rancangan Acak Kelompok (RAK) dengan 9 perlakuan yaitu : Glufosinate + surfaktan nonionik $15 \%$; Glufosinate + surfaktan anionik $15 \%$; Glufosinate + surfaktan kationik 15\% ; Glufosinate ; Glufosinate + surfaktan nonionik $20 \%$; Glufosinate + surfaktan anionik $20 \%$; Glufosinate + surfaktan kationik 20\% ; Penyiangan Mekanis ; Kontrol (tanpa perlakuan) ; diulang 3 kali untuk setiap perlakuan. Perbedaan antar perlakuan diuji dengan menggunakan uji $F$, sedangkan menguji perbedaan nilai rata-rata perlakuan digunakan uji Duncan pada taraf nyata 5\%. Hasil penelitian menunjukkan bahwa perlakuan Glufosinat tanpa surfaktan dapat menekan pertumbuhan gulma sehingga menunjukkan hasil tanaman terbaik dengan bobot rata-rata sebesar 12,41 ton/ha pipilan kering.

Kata kunci : Jagung · Glufosinat · Surfaktan

\section{Pendahuluan}

Jagung ( Zea mays L.) adalah salah satu tanaman pangan penting di Indonesia. Selain untuk pangan, jagung juga banyak digunakan sebagai pakan, bahan utama industri makanan, minuman, dan farmasi. Hal ini karena kandungan nutrisi pada jagung yang memiliki banyak manfaat yaitu sebagai sumber karbohidrat, asam lemak esensial, mineral, betakaroten, dan nutrisi lainnya yang dibutuhkan tubuh (Suarni, 2015). Berbagai manfaat yang dimiliki jagung membuat kebutuhan jagung di Indonesia terus meningkat. Menurut BPS (Badan Pusat Statistik, 2015), meskipun produksi jagung tahun 2015 yaitu 19,61 juta ton pipilan kering naik sebesar 0,62\% dibandingkan produksi jagung padatahun 2014 yaitu sebesar 19,01 juta ton pipilan kering, namun 
perkiraan kebutuhan jagung untuk konsumsi dan industri secara nasional mencapai 22 juta ton pipilan kering sehingga Indonesia masih mengimpor jagung sebesar 3-3,5 juta ton. Masih kurangnya ketersediaan jagung dapat ditingkatkan dengan memperbaiki teknik budidaya jagung salah satunya pengendalian gulma.

Menurut Purba (2009), kehilangan hasil jagung akibat persaingan dengan gulma adalah sebesar $31 \%$. Selain itu, beberapa penelitian menyatakan adanya interaksi negatif antara bobot kering gulma dan hasil jagung, kehadiran gulma dapat menurunan hasil hingga 95\% (Violic, 2000). Untuk menghindari terjadinya kerugian akibat keberadaan gulma maka diperlukan pengendalian gulma yang tepat.

Salah satu cara yang banyak dilakukan saat ini adalah pengendalian gulma dengan menggunakan herbisida karena cara ini dinilai lebih efisien dalam aspek biaya, waktu, dan tenaga kerja (Monaco dkk., 2002). Salah satu herbisida yang dapat digunakan dalam pengendalian gulma pada pertanaman jagung adalah herbisida dengan bahan aktif glufosinat. Glufosinat merupakan herbisida pascatumbuh yang bersifat kontak dan nonselektif yang dapat digunakan untuk mengendalikan gulma daun lebar serta gulma rumput (Tomlin, 2011).

Terdapat berbagai faktor lingkungan yang memengaruhi kinerja herbisida diantaranya suhu, angin, dan hujan. Faktor-faktor lingkungan ini dapat meningkatkan jumlah herbisida yang terbuang sehingga tidak efektif dalam mengendalikan gulma (Kudsk, 1992). Menurut Zabkiewicz (2007), kehilangan herbisida akibat droplet yang lepas dari target pada aplikasi herbisida mencapai 5-92\%. Diperkirakan dari total pestisida yang diaplikasikan dalam pengendalian OPT hanya sebagian kecil $(<0,1 \%)$ yang benar-benar mencapai tempat bekerjanya bahan aktif, sebagian besarnya hilang karena fotodegradasi, run-off, melayang akibat angin, dll (Pimentel, 1995). Untuk meningkatkan efektifitas herbisida dapat dilakukan penambahan surfaktan yang diharapkan dapat meningkatkan efektifitas herbisida yang diaplikasikan dalam mengendalikan gulma..

Surfaktan adalah senyawa yang mempunyai struktur bipolar dengan bagian kepala bersifat hidrofilik dan bagian ekor bersifat lipofilik. Surfaktan yang dicampurkan dengan herbisida berfungsi untuk mengurangi tegangan permukaan antara permukaan daun dan herbisida sehingga dapat memperluas penye- baran herbisida pada permukaan daun (Tominack, 2000). Perluasan area penyebaran herbisida pada permukaan daun menyebabkan menurunnya penguapan herbisida sehingga proses aplikasi herbisida lebih efisien (Damato, 2016).

Terdapat tiga jenis surfaktan yang sering digunakan yaitu surfaktan anionik, surfaktan nonionik dan surfaktan kationik. Surfaktan anionik adalah surfaktan dengan muatan negatif, surfaktan kationik adalah surfaktan dengan muatan positif, dan surfaktan nonionik adalah surfaktan yang tidak memiliki muatan (Rosen, 2004). Tujuan dari penelitian ini adalah untuk mengetahui pengaruh surfaktan serta jenis dan konsentrasi surfaktan yang efektif dalam membantu herbisida mengendalikan gulma pada pertanaman jagung menggunakan herbisida glufosinat.

\section{Bahan dan Metode}

Penelitian ini dilaksanakan di Kebun Percobaan Ciparanje, Fakultas Pertanian, Universitas Padjadjaran yang berlangsung dari September hingga Desember 2016.

Metode yang digunakan dalam penelitian ini Rancangan Acak Kelompok (RAK) yang terdiri dari 9 perlakuan dan diulang sebanyak 3 kali, sehingga diperoleh 27 satuan percobaan. Ukuran petak percobaan adalah $5,0 \times 6,0 \mathrm{~m}$. Perlakuan dalam percobaan ini adalah sebagai berikut :
A. Glufosinate + surfaktan nonionik $15 \%$
B. Glufosinate + surfaktan anionik $15 \%$
C. Glufosinate + surfaktan kationik $15 \%$
D. Glufosinate
E. Glufosinate + surfaktan nonionik $20 \%$
F. Glufosinate + surfaktan anionik $20 \%$
G. Glufosinate + surfaktan kationik $20 \%$
H. Penyiangan Mekanis
I. Kontrol (tanpa perlakuan)

Keterangan : Glufosinate $160 \mathrm{~g} / \mathrm{L}$ dengan dosis 2,5 L/ha (400 g b.a / ha). Aplikasi herbisida + surfaktan dilakukan pada 14 hari setelah tanam.

Pengaruh percobaan terhadap pertumbuhan tanaman dianalisis dengan analisis ragam uji $\mathrm{F}$ pada taraf nyata $5 \%$. Apabila terdapat perbedaan antar perlakuan maka analisis dilanjutkan dengan Uji Jarak Berganda Duncan pada taraf nyata $5 \%$.

Pengamatan dilakukan terhadap bobot kering gulma total pada 3 dan 6 minggu setelah 
aplikasi (MSA), tinggi tanaman jagung pada 1,3, dan 5 MSA, serta hasil tanaman jagung.

\section{Hasil dan Pembahasan}

Bobot Kering Gulma Total. Hasil pengamatan bobot kering gulma total pada 3 dan $6 \mathrm{msa}$ menunjukkan efek penekanan pertumbuhan gulma dilihat dari bobot kering gulma total perlakuan kontrol yang memiliki bobot kering paling tinggi dibandingkan dengan perlakuan penambahan herbisida. Menurut Chompoo and Pornprom (2008), herbisida glufosinat merupakan herbisida non selektif yang mampu mengendalikan berbagai jenis gulma. Herbisida glufosinat memiliki spectrum yang luas sehingga efektif mengendalikan gulma setahun dan tahunan baik dikotil maupun monokotil (Singh and Tucker, 1987).

Tabel 1. Pengamatan terhadap Bobot Kering Gulma Total Umur 3 dan 6 MSA (g).

\begin{tabular}{|c|c|c|c|c|}
\hline \multirow{3}{*}{$\begin{array}{c}\text { Perlakuan } \\
\text { A }\end{array}$} & \multicolumn{4}{|c|}{ Umur } \\
\hline & \multicolumn{2}{|c|}{$3 \mathrm{MSA}$} & \multicolumn{2}{|c|}{6 MSA } \\
\hline & 1.58 & C & 2.99 & bc \\
\hline B & 3.18 & bc & 9.66 & $b$ \\
\hline C & 1.01 & c & 4.23 & bc \\
\hline D & 1.05 & C & 2.59 & $\mathrm{c}$ \\
\hline $\mathrm{E}$ & 2.59 & bc & 7.45 & bc \\
\hline $\mathrm{F}$ & 5.26 & bc & 5.08 & bc \\
\hline G & 2.88 & bc & 4.96 & bc \\
\hline $\mathrm{H}$ & 16.98 & $\mathrm{~b}$ & 8.08 & bc \\
\hline I & 102.31 & $\mathrm{a}$ & 133.59 & $\mathrm{a}$ \\
\hline
\end{tabular}

Ket : Nilai rata-rata yang diikuti huruf yang sama menunjukkan tidak berbeda nyata menurut Uji Jarak Berganda Duncan pada Taraf 5\%

Pengamatan terhadap bobot kering gulma total pada 3 perlakuan A, B, C, D, E, F, dan G menunjukkan hasil yang tidak berbeda nyata, Sedangkan pada pengamatan 6 MSA menunjukkan perlakuan A-H memiliki hasil yang tidak berbeda nyata. Penambahan surfaktan pada larutan herbisida memiliki hasil yang berbeda karena surfaktan akan memiliki reaksi yang berbeda terhadap senyawa kimia yang berbeda pada jenis tumbuhan yang berbeda (Stock et al, 1993).

Tinggi Tanaman Jagung. Pengamatan tinggi tanaman jagung yang dilakukan pada umur 1, 3, dan 5 MSA. Pengamatan 1 msa menunjukkan hasil yang tidak berbeda nyata, hal ini diduga karena keberadaan gulma yang berkurang akibat aplikasi herbisida membuat gulma tidak mampu bersaing dengan tanaman jagung sehingga tinggi tanaman jagung tidak terpengaruh.

Tabel 2. Pengamatan terhadap Tinggi Tanaman Jagung (cm).

\begin{tabular}{|c|c|c|c|c|c|}
\hline \multirow{2}{*}{ Perlakuan } & \multicolumn{5}{|c|}{ Umur } \\
\hline & \multicolumn{2}{|c|}{$1 \mathrm{MSA}$} & \multicolumn{2}{|c|}{3 MSA } & 5 MSA \\
\hline A & 49.16 & $\mathrm{a}$ & 130.81 & $\mathrm{a}$ & $159.49 \mathrm{ab}$ \\
\hline B & 51.30 & $\mathrm{a}$ & 131.38 & $\mathrm{a}$ & $166.33 \mathrm{ab}$ \\
\hline $\mathrm{C}$ & 49.84 & $\mathrm{a}$ & 124.33 & a & $154.21 \mathrm{~b}$ \\
\hline $\mathrm{D}$ & 46.64 & a & 125.13 & $\mathrm{a}$ & $157.26 \mathrm{ab}$ \\
\hline E & 45.57 & a & 130.86 & $\mathrm{a}$ & $169.68 \mathrm{ab}$ \\
\hline F & 54.03 & $\mathrm{a}$ & 141.52 & $\mathrm{a}$ & $175.87 \mathrm{a}$ \\
\hline G & 47.26 & $\mathrm{a}$ & 129.58 & $\mathrm{a}$ & $165.19 \mathrm{ab}$ \\
\hline $\mathrm{H}$ & 49.52 & a & 119.16 & $\mathrm{a}$ & $157.50 \mathrm{ab}$ \\
\hline $\mathrm{I}$ & 44.62 & $\mathrm{a}$ & 88.74 & b & $121.75 \mathrm{c}$ \\
\hline
\end{tabular}

Ket : Nilai rata-rata yang diikuti huruf yang sama menunjukkan tidak berbeda nyata menurut $\mathrm{Uji}$ Jarak Berganda Duncan pada Taraf 5\%

Pengamatan umur 3 dan 5 MSA menunjukkan perlakuan I (kontrol) meumiliki hasil paling rendah dan berbeda nyata dengan perlakuan lainnya. Menurut Nieto et al. (1968) gulma dapat mengganggu pertumbuhan tanaman melalui kompetisi terhadap air, cahaya, dan nutrisi, selain itu gulma juga dapat mengganggu pertumbuhan tanaman dengan menjadi inang hama dan penyakit.

Tabel 3. Hasil Pipilan Kering Tanaman Jagung. Hasil Pipilan Hasil Pipilan

Perlakuan Kering per Ubinan Kering per Hektar

\begin{tabular}{cllll} 
& \multicolumn{2}{c}{$(\mathrm{kg})$} & \multicolumn{2}{c}{ (ton) } \\
\hline $\mathrm{A}$ & 5.61 & $\mathrm{ab}$ & 11.23 & $\mathrm{ab}$ \\
$\mathrm{B}$ & 6.06 & $\mathrm{ab}$ & 12.11 & $\mathrm{ab}$ \\
$\mathrm{C}$ & 5.82 & $\mathrm{ab}$ & 11.65 & $\mathrm{ab}$ \\
$\mathrm{D}$ & 6.21 & $\mathrm{a}$ & 12.41 & $\mathrm{a}$ \\
$\mathrm{E}$ & 5.56 & $\mathrm{ab}$ & 11.12 & $\mathrm{ab}$ \\
$\mathrm{F}$ & 5.97 & $\mathrm{ab}$ & 11.95 & $\mathrm{ab}$ \\
$\mathrm{G}$ & 5.82 & $\mathrm{ab}$ & 11.65 & $\mathrm{ab}$ \\
$\mathrm{H}$ & 5.31 & $\mathrm{~b}$ & 10.61 & $\mathrm{~b}$ \\
$\mathrm{I}$ & 4.25 & $\mathrm{c}$ & 8.49 & $\mathrm{c}$ \\
\hline \hline
\end{tabular}

Hasil Tanaman Jagung. Hasil analisis bobot pipilan kering per ubinan seluas $4 \mathrm{~m}^{2}$ dan hasil pipilan kering konversi ke hektar (ton) menunjukaan bahwa perlakuan I (kontrol) memiliki bobot pipilan kering paling rendah, hal ini diduga karena tanaman jagung harus berkompetisi dengan gulma sehingga tanaman tidak optimal dalam menyerap unsur hara.

Penambahan surfaktan pada herbisida menunjukkan hasil yang tidak berbeda nyata 
terjadi karena surfaktan akan memiliki pengaruh yang baik pada herbisida yang sesuai, dosis yang sesuai, dan formulasi yang sesuai (Castro et al., 2013) sehingga masih diperlukan penelitian lebih spesifik mengenai kesesuaian surfaktan terhadap herbisidaglufosinat.

\section{Kesimpulan}

Tidak terdapat jenis dan konsentrasi surfaktan yang berpengaruh terhadap pengendalian gulma dan hasil tanaman jagung pada pengendalian kimia menggunakan glufosinat. Herbisida glufosinate $160 \mathrm{~g} / \mathrm{L}$ dengan dosis 2,5 L/ha tanpa surfaktan efektif dalam mengendalikan gulma total yang terdapat di lahan percobaan sampai dengan 6 minggu setelah aplikasi serta memberikan hasil yang lebih baik pada hasil tanaman jagung dibanding perlakuan dengan penambahan berbagai jenis dan konsentrasi surfaktan.

\section{Daftar Pustaka}

Anderson, Wood Powell. 1977. Weed Science: Principles. New Mexico State University Las Cruces, New Mexico

Badan Pusat Statistik.2015. Produksi Jagung Menurut Provinsi (ton), 1993-2015. Diakses secara online melalui http://www.bps.go.id/ pada 15 November 2016

Castro., Mariano J. L., Carlos Ojeda, Alicia Fernandez Cirelli. 2013. Surfactants in Agriculture Dalam Buku Green Materials for Energy, Products and Depollution, 287-334

Chompoo, J., and T. Pornprom. 2008. RT-PCR based detection of resistance conferred by an insensitive GS in glufosinate-resistant maize cell lines. Pesticide Biochem. Physiol. 90:189195

Harjadi, S. S. 1993. Pengantar Agronomi. Gramedia. Jakarta (2017) 57-65

Kudsk, P., J.L. Kristensen. 1992. Effect of environmental factors on herbicide performance. Proceedings of the first International Weed Control Congres, Melbourne
Monaco, T.J., S. M. Weller., F. M. Ashton. 2002. Weed Science. Principles and Practice. $4^{\text {th }}$ ed. John Wiley \& Sons New York

Nieto, H., Jorge, M.A. Brondo, J.T. Gonzalez. 1968. Critical Periods of the Crop Growth Cycle for Competition from Weeds. PANS Vol. 14 No. 2.

Pimentel, D. 1995. Amounts of pesticides reaching the target pests: environmental impacts and ethics. J Agric Environ Ethics 8:17-29

Purba, E. 2009. Keanekaragaman herbisida dalam pengendalian gulma mengetasi populasi gulma resisten dan toleran herbisida. Pidato Pengukuhan Jabatan Guru Besar Tetap dalam Bidang Ilmu Gulma pada Fakultas Pertanian Universitas Sumatera Utara. Medan, http://www.usu.ac.id/ diakses 16 November 2016

Rosen MJ. 2004. Surfactants and Interfacial Phenomena. Third edition. Wiley Interscience New York

Singh, M and D. P. H. Tucker. 1987. Glufosinate (ignite) : A New Promising Postemergence Herbicide for Citrus. Florida Agricultural Experiments Station Journal Series No. 8630, 58-61

Stock, D., P. J. Holloway, B. T. Grayson, and P. Whitehouse. 1993. Development of a predictive model to rationalize selection of polyoxyethylene surfactant adjuvants for foliage-applied agrochemicals. Pestic. Sci 37:233-245

Suarni., Muh, Yasin. 2015. Jagung sebagai Sumber Pangan Fungsional. Iptek Tanaman Pangan Vol. 6 No 1-2011

Tominack, R.L., 2000. Herbicide formulations. J. Toxicol. Clin. Toxicol. 38, 129-135.

Tomlin, C. D. S. 2011. The e-Pesticides Manual Version 3.0 (thirteenth edition). British Crop Protection Council

Violic, A. D. 2000. Integrated crop management. In: R. L. Paliwal, G. Granados, H.R. Lafitte, A.D. Violic, anf J.P. Marathee (Eds.). Tropical Maize Improvement and Production Series, FAO. Rome, 28:237-282

Zabkiewicz, J. A. 2007. Spray Formulation EfficacyHolistic and Futuristic Perspectives. Crop Protection, 26 (3), 312-319 